
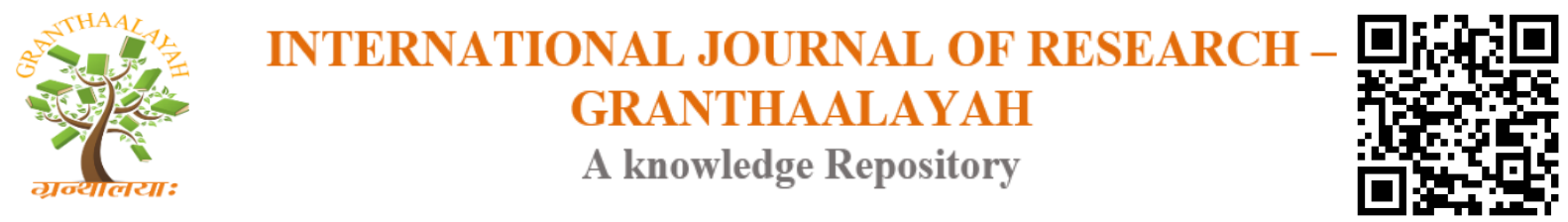

Management

\title{
HUMAN-INDUCED MORTALITY INCIDENCE ON THE SOCIO- ECONOMIC DEVELOPMENT OF OKU SUB-DIVISION, NORTH WEST REGION OF CAMEROON
}

\author{
Bailack Kevin Mbuh ${ }^{1}$, Lawrence F. Fombe ${ }^{2}$ \\ ${ }^{1}$ Department of Geography and Planning, The University of Bamenda Cameroon \\ ${ }^{2}$ Higher Institute of Transport and Logistics, The University of Bamenda Cameroon
}

\begin{abstract}
Mortality, which is inevitable and irrevocable, has been a major threat to mankind. Human-induced fatalities are still distressing in Oku Sub-Division. The degree of exposure of the population is very high wherein settlement and village activities are sited on montane steep slopes which are susceptible to landslides and extreme weather conditions. This is couple with poor access to healthcare. Human-induced mortality triggers and implications on the population of Oku needs to be seriously addressed in contemporary era. As such, this study uses a historical survey and comparative design of field investigation covering a period of 36years (1982 to 2018) to examine the human related scourges of mortality in Oku. Purposive sampling technique was used to administer questionnaires to selected key informants as well as through focus group participants from the entire population. Findings from a Chi-Square Test at 0.05 level of significance and a df of 6 portray that human-induced mortality incidence limits to an extent or is a deterrent to the socio-economic development of Oku leading to the conclusion that rapid population growth and limited space for settlement on the precarious mountainous environment is the key stressor on human life. Educating the population to avoid precipitous slopes susceptible to landslides can safe humanity, ensure sustainable livelihood and increase assets for socio-economic development.
\end{abstract}

Keywords: Socio-Economic Development, Exposure, Landslides, Mortality, Oku.

Cite This Article: Bailack Kevin Mbuh, and Lawrence F. Fombe. (2020). "HUMAN-INDUCED MORTALITY INCIDENCE ON THE SOCIO-ECONOMIC DEVELOPMENT OF OKU SUBDIVISION, NORTH WEST REGION OF CAMEROON." International Journal of Research Granthaalayah, 8(4), 32-46. https://doi.org/10.29121/granthaalayah.v8.i4.2020.5.

\section{Introduction}

Mortality is a natural phenomenon in the world that befalls and can affect every population. It is inevitable and irrevocable in human societies regardless of age and location from creation. Globally, it is however distressing to socio-economic development when human-induced mortality rates are increasing as it reduces population numbers which is considered as a major asset of socioeconomic development (Javier, 2007). In the developed world, the rate of human-induced 
mortality has dropped drastically from 32\% in 1990 to $18 \%$ in 2013 (UNO, 2015). This decline stems from the increase in per capita incomes, high living standards, the improvement in public healthcare status and education. All these indices have brought about a corresponding rise in the socio-economic development rates bequeathed to these developed countries by declining death rates (UNO, 2017). However, rapid urbanization and the $21^{\text {st }}$ Century lifestyles have ushered in health hazards in developed countries: tobacco use, unhealthy diet, insufficient physical activity, poor use of highways and the harmful consumption of alcohol are the major causes of relatively minimal mortality in developed countries which have a little significance in the socio-economic development of this region (WHO, 2010); Cutler et al., 2006).

In the developing world, human-induced mortality rates are still more evidently superseding global decline by $9.6 \%$ especially in Sub-Saharan Africa. The impact of the proposed MDGs in the year 2000 , with the $4^{\text {th }}$ target calling for the reduction in the mortality rate by two third between 1990 and 2015 and the recent past Global Strategy for Women's and Children's Health launched by the UNO heightening global momentum in reducing mortality rates in developing countries have not been felt in this part of the continent especially in many parts of Southern Asia and South America where mortality rates are still very disquieting (Jesse et al., 2013).

The prominent causes of deaths in developing countries are due to the high rates of exposure to birth complications, pneumonia, birth asphyxia, diarrhoea and malaria; with about $45 \%$ of global child deaths linked to malnutrition (Ayres and Hurley, 2010). The exposure to air, water and land pollution can result in serious health problems and consequently death (Lucyna, 2016). When human numbers are exposed to these social problems, mortality rates heighten. When human numbers decrease in an alarming rate resulting from physical and human hazards, assets for socioeconomic development are reduced as population (human capital) is the main driver of socioeconomic development. This explains why most economies of the high mortality ridden parts of Africa still have very low and disturbing levels of socio-economic development (World Bank, 2007).

Cameroon is still experiencing higher human-induced hazards and mortality rates that worsen levels of socio-economic development compared to some regions in the world. Access to basic healthcare services for children less than 5 years and pregnant women are inadequate. The health of children and women are endangered further by the lack of safe and sufficient water supplies and proper sanitation facilities (Centre for Disease Control and Prevention, 2016); and some inhabitants still live on endangered geo-hazard landscapes susceptible to landslides and strong winds (Fogwe, 2010). Most of the inhabitants who cannot afford for the healthcare services end up dying in very precarious health conditions. The poor health conditions of the labour force; the already low per capita incomes of the population are used for the purchase of healthcare services and the loss of human population to mortality results in little rates of capital and human investments which is a vital aspect of socio-economic development (UNICEF, 2011).

Oku in particular is a rural community with demographic characteristics which still replicate the features of stage one of the Demographic Transition Model. Birth and death rates are still high and fluctuating (Tangwa, 2009). Mortality incidences are still widespread with common prevalence being human-induced mortality with incidence very significant in reducing family and village labour force and income for community socio-economic development. According to the Elak 
District Hospital Records (2018) mortality rates are still excruciating. Some inhabitants in Oku still have a poor perception about modern medication and the dangers of steep slopes for settlements and agriculture given the increasing population density from 23 persons $/ \mathrm{Km}^{2}$ in 2005 to over 39 persons $/ \mathrm{km}^{2}$ in 2013 (Elak Council Development Plan, 2012). This has occasioned high exposure to human casualties widening the mortality scope which therefore reduces the assets for socio-economic development through the loss of human and financial resources and the disruption of economic activities.

The rationale of this study is to identify the human-induced mortality causes and implications on the population of Oku Sub-Division. This study is based on the premise that human-induced mortality incidence limits to an extent the socio-economic development of Oku. The period between 1982 and 2008 coincides with the upsurge of inter-tribal conflicts in Oku. The creation of the Kilum Mountain Forest Reserve in 1987 and reinforced by the 1994 forestry law limited the land for livelihoods and opportunities thereby obligating the people to occupy steep Kilum montane slopes as a means for survival. 2009-2018 was marked by rapid population growth, food crisis and the migration to hollow frontiers to avert food insecurity. 2015 witnessed the tarring of the Ndop-Oku road which tremendously amplified fatality rates of accidents in Oku Sub-Division.

\section{Study Area and Methodology}

The study area falls between latitude $6^{\circ} 8^{\prime}$ to $6^{\circ} 16^{\prime}$ North and $10^{\circ} 30^{\prime}$ to $10^{\circ} 36^{\prime}$ East stretching over $276.87 \mathrm{~km}^{2}$ comprising 36 villages with 182,879 inhabitants (CDP, 2017; BUCREP, 2005). This study was carried out using a historical survey and comparative approach of field investigation and observations. It covered a 36-year period from 1982 to 2018. The comparative design recounts the different triggering mechanisms of mortality in the different periodical trends which constitute the main premise of the study.

A purposive sampling technique from the four mountainous zones with slopes as follows: Mbai (6.1-9.5\%), Emfve-miih (3.1-6\%), Mbam (13.6-25\%) and Shinga zone (9.6-13\%) in the villages that make up Oku Sub-Division was used. Primary data was collected from the field through three complementary techniques involving questionnaires, formal and informal interviews and direct observation of building sites, measurement of slope gradients (3.1-25\%) and the human activities on steep slopes. Some 200 questionnaires were administered to the target population of 1000 inhabitants (20\% of the target population).

The target population were those living and practicing agro-activities on steep slopes. Those living by the road sides and border areas were included. Based on the population of these four zones, a $20 \%$ sample size was considered to representatively portray the degree of human exposure to mortality. Traditional authorities and some village elders were interviewed for having observed the evolution of human-induced hazards and mortality as well as the impacts. Primary data was complemented by secondary data obtained from Elak Council, District Hospital and Health Centres, Oku Fon's palace, church and parish documents as well as published and unpublished documents. Descriptive and inferential statistical techniques were used to relate human exposure, mortality and implications on the population. 


\section{Results and Discussions}

The outstanding concern in this study is to illustrate the extent to which anthropogenic activities on the montane region characterised by precipitous slopes, poor modern healthcare accessibility and inter-tribal conflicts contribute to human fatalities by addressing their various livelihood activities serving as major triggers.

\subsection{Human-induced Mortality in Oku}

Human-induced mortality in Oku is experiencing a high prevalence rate based on the fact that land use practices on the Kilum Montane steep slopes in a mountainous environment, poor population's perception to modern healthcare delivery and conflicts expose them fatalities. This is consistent with the notion of Windsor et al. (2014) who partially considered the cause of human induced mortality to result only from settlement in poor relief environment. Rates are high with an annual average of 07 deaths per zone. There is an uneven distribution of these rates. Oku is sited in a mountainous region but bounded to the South by Babungo and to the North by Noni which are low lying zones. To the West with Fundong and East with Jakiri which are areas with steep slopes (Figure 1). These disparities in relief cause human mortality to fluctuate. Specific villages close to steep slopes like Simonkoh, Lum, Ntowel (Mbai Zone) and Ngashie Jikejem, Chia, and Kesoten (Emfve-miih zone) have high degree of exposure. In contrast, Mbam, Mbacham Chak and Ibal have limited exposure.

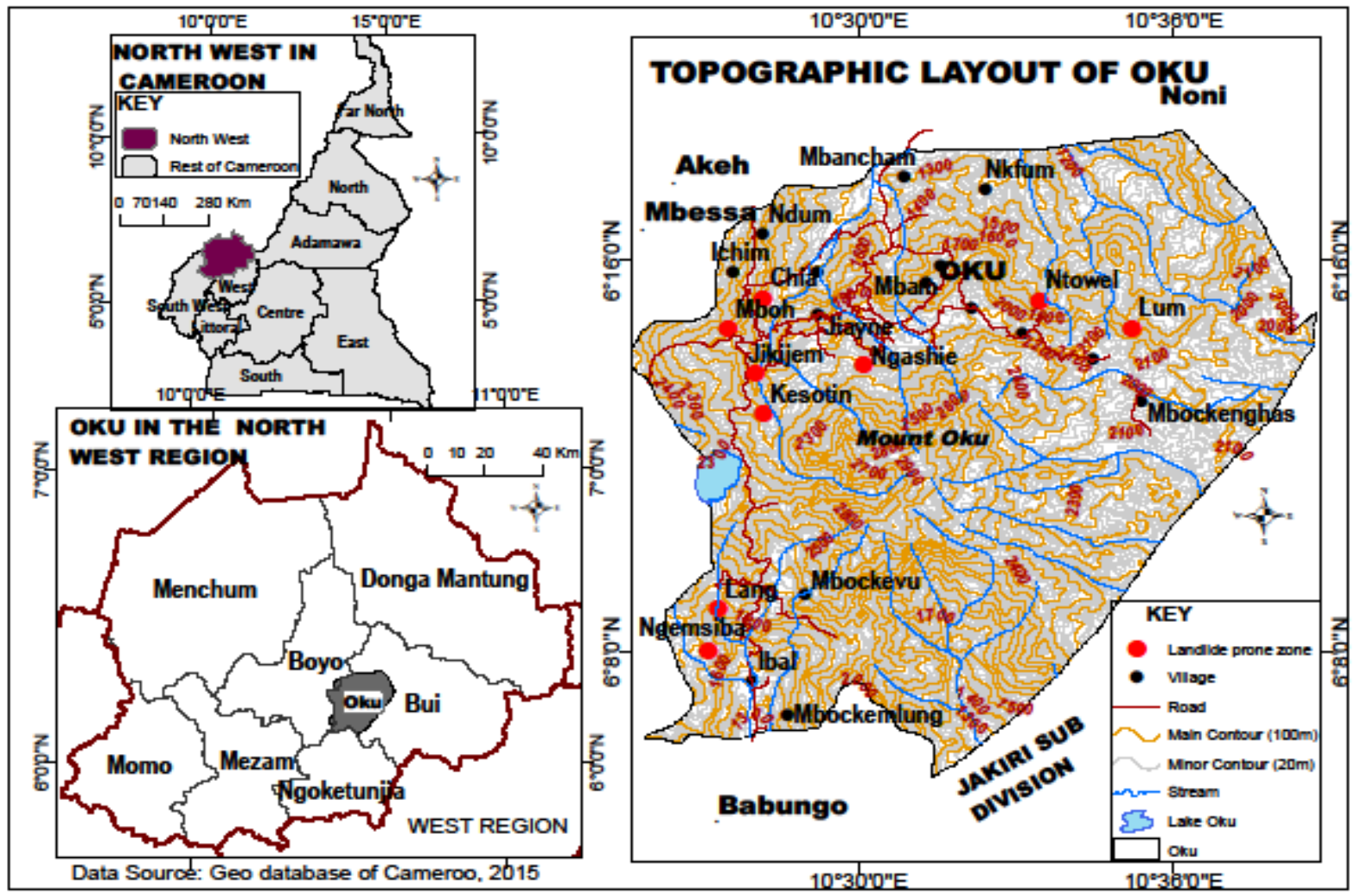

Figure 1: The layout of Oku Sub-Division and zones prone to human-induced mortality Source: Administrative units of Cameroon 2011NIC Yaounde; Fieldwork supported by Landsat 8, 2017. 
The landslide prone zones are areas of human-induced mortality. These areas have rugged topographies with most of them ranging between 6 and 25\% (Figure 2). Landslides are frequent every year especially in the months of July, August and September which is the heart of the rainy season in this area. Variations in exposure to landslides and extreme weather conditions are a function of human-induced mortality and natural hazards. The climate of Oku is highland interior type marked by high annual torrential rainfall ranging from $2200 \mathrm{~mm}$ to $3000 \mathrm{~mm}$ (Fogwe and Kwei, 2015). Temperature ranges from $20-25.9^{\circ} \mathrm{C}$ but drops below $20^{\circ} \mathrm{C}$ in the mountainous zones and the forest (Elak Council, 2018). The area is characterised by steep slopes (30\%) ending up in valleys and undulating landscapes with some inhabited areas as high as $2000 \mathrm{~m}$ in altitude. This area is characterised by rugged relief with geomorphic features ranging from highlands to lowlands with the highest peak attaining $3011 \mathrm{~m}$ in altitude, culminating in Mount Oku (Kilum/Ijim) the second highest peak in West Africa (Fogwe and Kwei, 2015). Low temperatures and steep slopes such as in Mbai and Emfve-miih zones are exposed to hazards. This is supported by Fogwe (2010) who pointed out that those geo-hazard areas in Cameroon trigger mortality incidences in the population.

\subsection{Triggers and impact of human-induced mortality in Oku}

Human-induced mortality in Oku is triggered by a number of physical and human factors. These elements range from exposure to hazards, socio-cultural to economic vices. For the purpose of this study, the triggering mechanisms of human-induced mortality on the population are grouped based on major variables of physical and human exposure to a difficult environment causing deaths with casualties from 1982-2018 (figure 2).

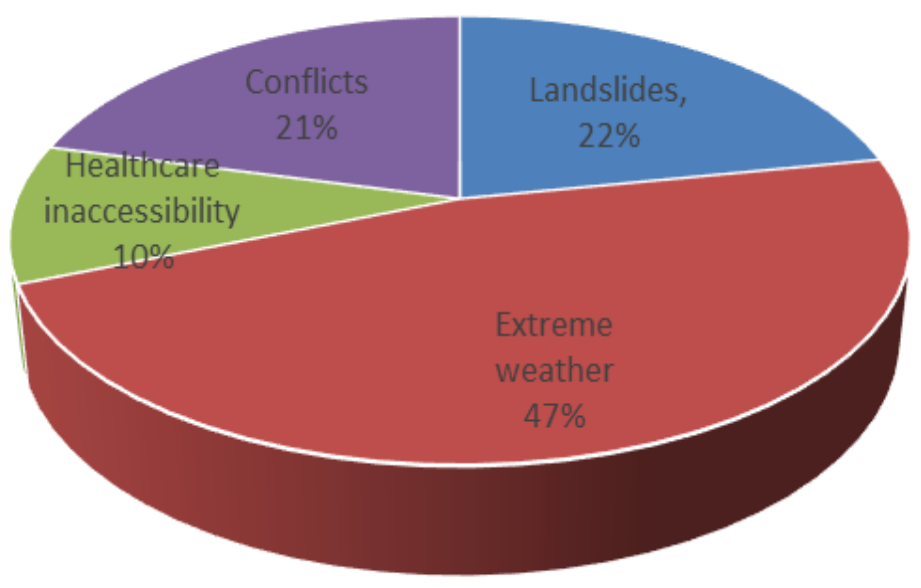

Figure 2: Major causes of human induced mortality in Oku Sub-Division

Source: Fieldwork, 2018

This analysis alludes to the fact that rising mortality numbers especially in periods of landslides, extreme weather and conflicts and in an environment which has poor healthcare accessibility spatiotemporally reduce the assets for development through a loss in labour force and income for community development. 


\subsubsection{Human-Induced Hazards and High Vulnerability of the Population}

This is the most important and prime triggering mechanism. The rapid population growth, limited space for settlement and agriculture and land related disputes have obliged majority of the population to solicit steep slopes for settlement and other land uses (Plate 3.1).

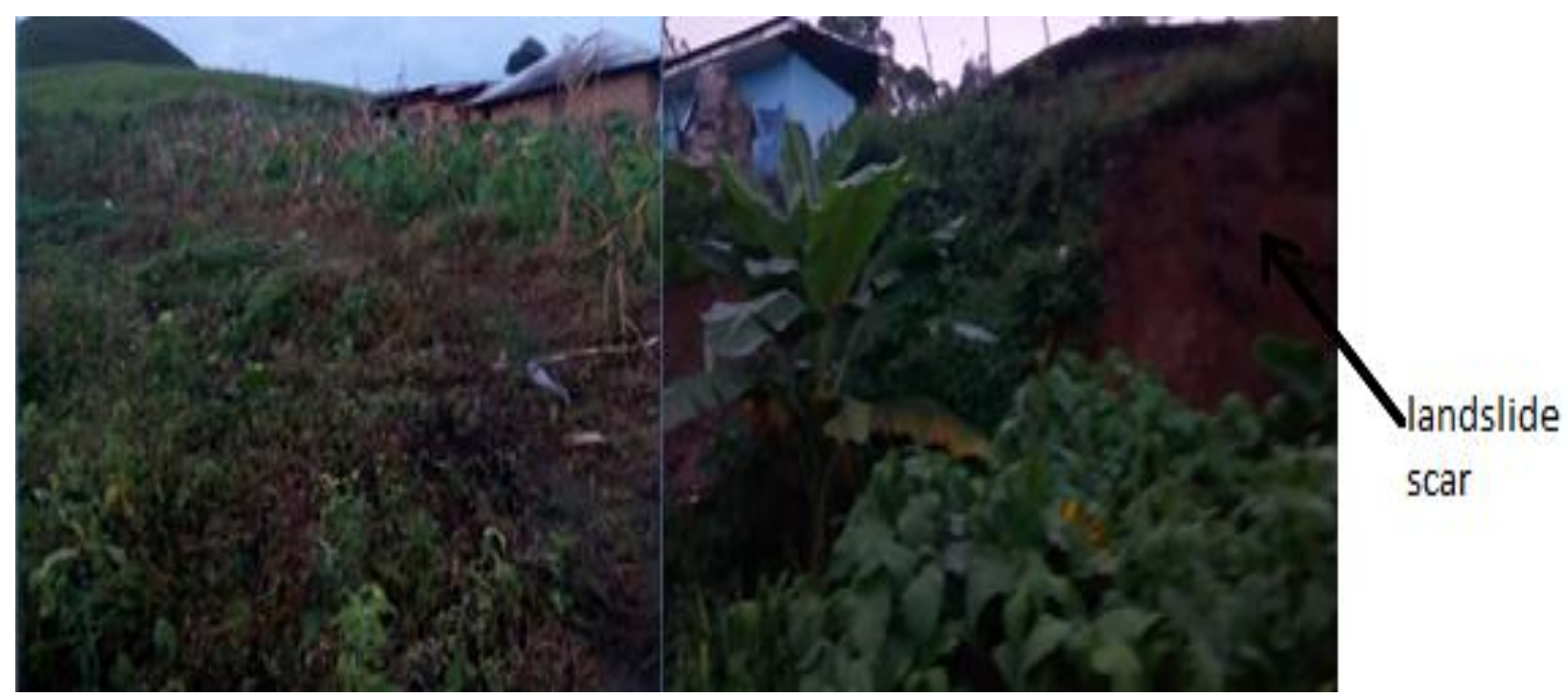

A

B

Plate 1: Farming and settlements on steep slopes in the locality of Kesotin-Oku Source: Fieldwork, 2018

Plate 1A indicates farmlands and houses located on steep slopes (slope angles ranging between 9 and $13 \%$ ). These farmlands frequently grieve from landslides on a seasonal basis. The houses are built on top of the slope and risk collapsing. Plate1B indicates a building at the verge of collapse due to a landslide (slope angle ranging from 13 to 25\%). The land slip shown in Plate $1 \mathrm{~B}$ occurred in July 2016 and caused the collapse of a house that left the inhabitants homeless and injuring 3 people. All this reduces farm output and per capita income for development.

These buildings on steep slopes principally in Gham, Chia, Ntowel, Lang Bow, Ichim, Kesoten, Lum and Jikejem weakens and increases slope loads causing slope failures. Slope angles measure between 13 and 25\%. Tilling and weakening of the slopes trigger landslides mostly common in the rainy season as shown in Figure 3. 


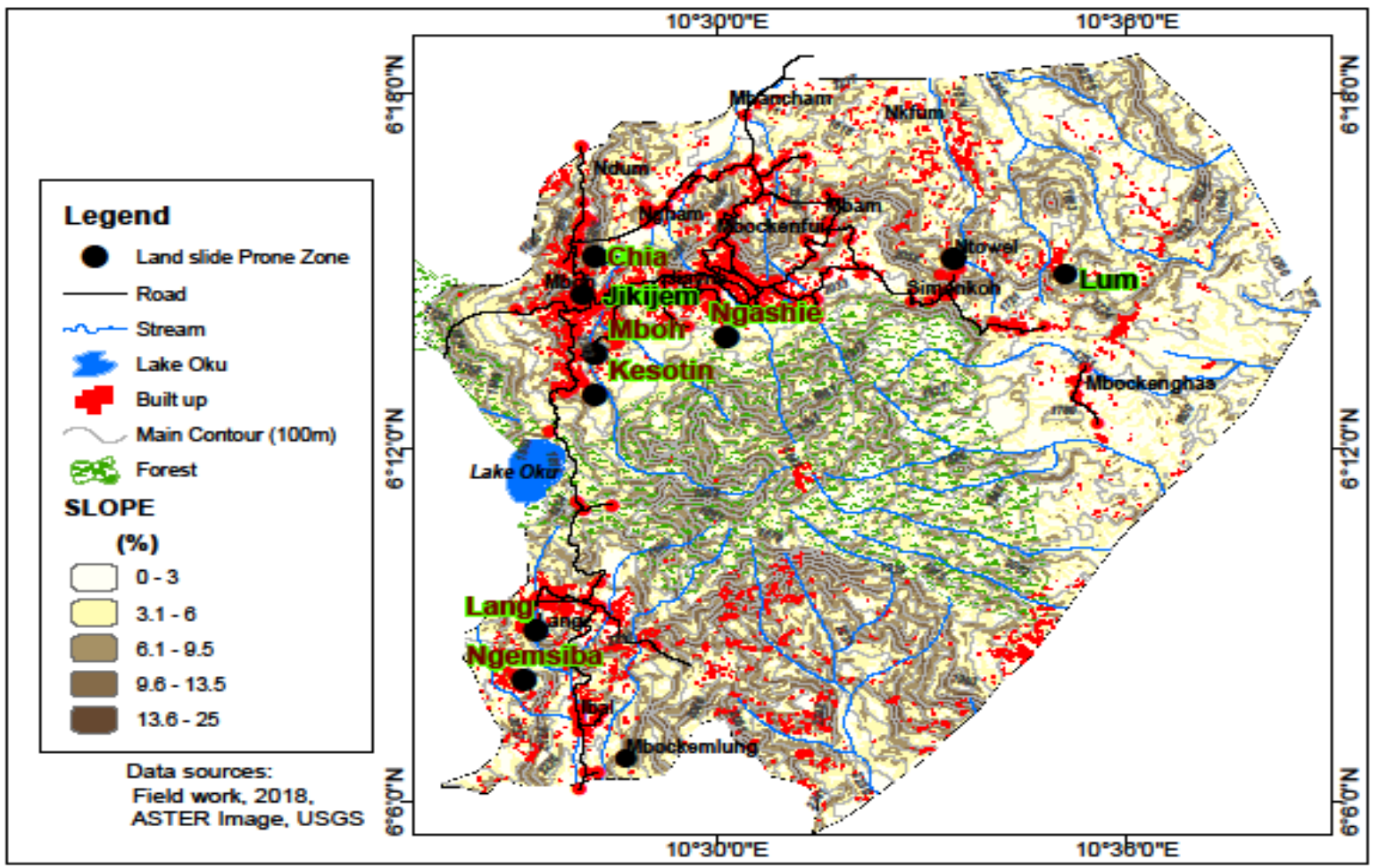

Figure 3: Slope angles and the degree of exposure of the population to landslides in Oku subdivision

Source: Fieldwork, 2018 supported by Landsat 8, 2017

Majority of these steep slopes ranging between $6 \%$ and $25 \%$ are exposed to climatic hazards like strong winds and very cold conditions that expose the population to diseases like Tuberculosis, Pneumonia and Catarrh which are also some major causes of deaths in the rainy season especially in Kesoten, Lang, Jikejem, Chia, Lum and Ntowel. This deviates from the conclusions of the WHO (2010) that considered the causes of human induced mortality as habits from poor lifestyle resulting from the high consumption of tobacco, unhealthy diet, insufficient physical activity and the harmful use of alcohol among blacks. The populations' perception on human exposure to hazard fatalities is shown in Table 1.

Table 1: Perception of inhabitants on reasons for soliciting steep slopes for human activities

\begin{tabular}{|l|l|l|l|l|l|}
\hline Reason & SA & A & N & SD & D \\
\hline Poor topography & & & & & \\
\hline High population growth & & & & & \\
\hline Limited space & & & & & \\
\hline Land disputes & & & & & \\
\hline
\end{tabular}

$S A=$ Strongly Agree, $\boldsymbol{A}=$ Agree, $\boldsymbol{N}=$ Neutral, $\boldsymbol{S D}=$ Strongly Disagree and $\boldsymbol{D}=$ Disagree .

Source: Fieldwork, 2019

Table 1 show that poor topography among high population growth and limited space is the major cause land use practices on steep slopes. This is clear in figures 1 and 2 which indicate that almost all of Oku is a mountainous environment with few plains common only in the Mbam zone. The inhabitants have little alternatives for the livelihoods as they are forced to allocate land uses on 
these slopes considering the raid population growth. This weakens the slopes leading to failure. When slope failure occurs, houses, crops, farmlands, livestock and other properties are buried and lost as well as roads cut-off as was the case during the 2017 landslides of Jikejem village (Plates 2A and 2B). People were also injured and as in the Lum landslide (Plate 2C) of 1989, 12 people were killed in the long run. All the material and crop damages with human casualties were accompanied by the halting of economic activities along the Oku-Ndop-Bamenda road. This is always very common on the rainy season along this road especially along the slopes of Shinga and reducing development assets (human and financial) and slowing down the socio-economic development chances of this area through reduction in transportation working days and incomes that are diverted to combat the effects of material damages. This is in accordance with the view of Tangwa (2009) that landslides in Oku reduces the assets of development by destroying property, shrinking the labour force and reducing the rate economic activities.

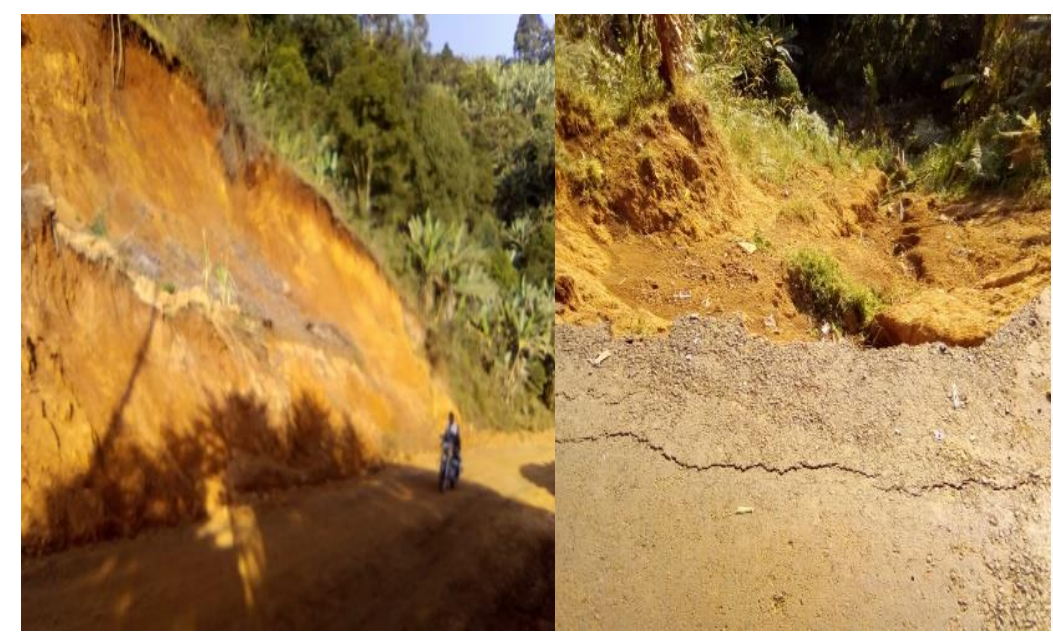

A
B

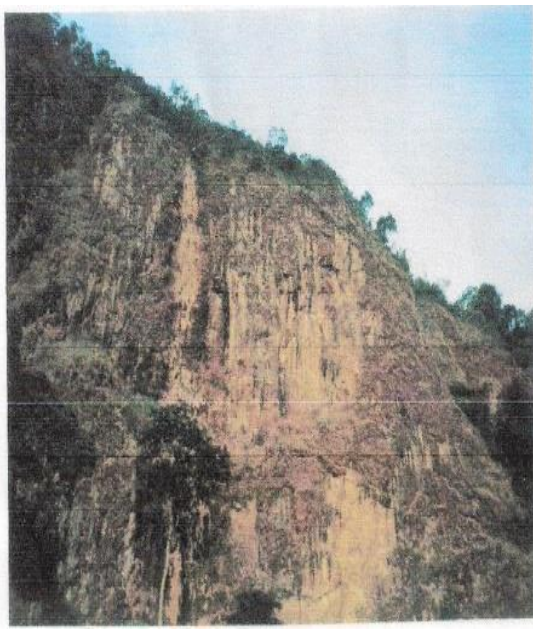

C

Plate 2: Landslides scars in Oku Sub-Division

Source: Fieldwork, 2019.

In the 2017 landslide, the road was blocked for a week, traffic and economic activities disrupted and cost the Council and other partners over a million CFA (>1,600USD) to clear the road. Information from village heads of Jikejem and Lum indicate that the 3 landslides in Figure 2 killed a total of 8 people, injured 4, buried a house and destroyed 13 farms with crops mostly in Lum village. All these casualties were a setback to developmental efforts in the affected areas. This evidence points to the fact that mortality due to exposure to human-induced hazards does not only affect population numbers and structure but also retards socio-economic development of Oku. This analysis opposes the ideas of Javier (2007) who opined that there has been a reduction in mortality rates in the $20^{\text {th }}$ and $21^{\text {st }}$ Century increasing economic growth and development. An evaluation of the population's consideration on the damages caused by landslides in Oku from 1994-2018 shown in Figure 4. 


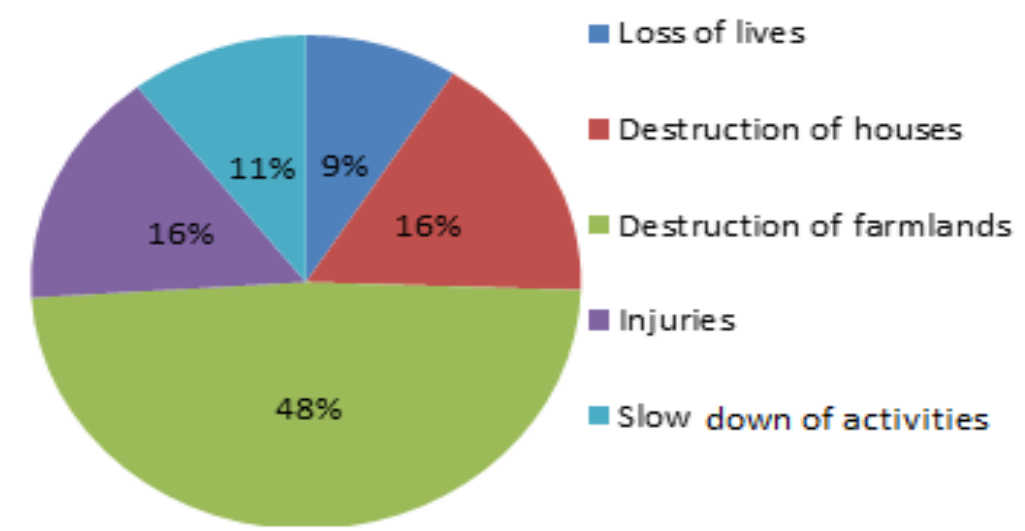

Figure 4: Damages caused by landslides from 1994-2018.

Source: Fieldwork, 2019 and Elak District Hospital, 2018.

Figure 3 indicates that the destruction of farmlands (48\%) is the highest damage caused by these landslides. Here, agricultural output which constitutes the major source of income for the population is reduced. This is reflected in reduced contributions on village development projects in the areas where these hazards are common like in Lum and the Shinga zone. The small proportion of lives lost (9\%) is due to the fact that the effects of landslides on human mortality in this area are not direct nor in the short-term but reflected in the long-run sufferings from injuries, destructions, displacements and lack of shelter. Table 2 presents the number of deaths due to longrun, multiplier and long run effects of landslides from 1989-2017.

Table 2: Landslides related casualties in Oku from 1989 to 2017

\begin{tabular}{|l|l|c|l|}
\hline Year & Locality of casualty & Number of deaths & Long term cause of mortality \\
\hline 1989 & Lum & 12 & $\begin{array}{l}\text { Massive displacement of people and lack } \\
\text { of shelter }\end{array}$ \\
\hline 1990 & Kfum & 01 & Injuries and poor access to treatment \\
\hline 1999 & Ntowel & 02 & Injuries by boulders \\
\hline 2003 & Lang & 01 & Displacement and poor shelter conditions \\
\hline 2010 & Chia & 01 & $\begin{array}{l}\text { Body injuries on the slidding mass of soil } \\
\text { and rocks }\end{array}$ \\
\hline 2016 & Kesoten & 03 & Injuries by rock boulders \\
\hline 2017 & Jikejem & 02 & Injuries by a mass of rock \\
\hline Total & & 22 & \\
\hline
\end{tabular}

Source: Tangwa, 2009, Elak Parish, 2009; Fieldwork, 2018

From table 2, most of the long term effects of landslides on human mortality are in the locality of Lum with 12 casualties. Field surveys indicate that this area has the steepest relief in Oku with slopes ranging between $13 \%$ and $25 \%$. The zone has been regarded as endemic to landslides due to the frequency and the massive destructions of 1989. Most of the deaths were long term illness from injuries. These deaths are mostly farmers who were caught by these slides in their farms and later on died from poor handling of their injuries. 


\subsubsection{Socio-Cultural and Economic Practices}

Inadequate social facilities like pipe borne water, medical facilities and obnoxious traditional practices enhance mortality. Statistics from the different health centres in Oku indicate that typhoid fever and stomach problems are increasing in the villages of Lum, Ntowel, Chak, Ngashie, Lui, Ndum, Chianghka and Ngham due to the deficiency of portable water. With a population of more than 100000 inhabitants the ratio of doctor to patients is 1: 3620 (Table 2). There is only one district hospital and 16 health posts. The problems of healthcare accessibility resulting from poor perception of the population on modern medication and financial constraints have also claimed so many lives as seen in table 3 .

Table 3: Demographic, socio-cultural and mortality situation in Oku Sub- Division between 1982 and 2018

\begin{tabular}{|l|c|c|c|l|c|}
\hline Zone & $\begin{array}{c}\mathbf{N}^{\mathbf{0}} \text { of } \\
\text { Health } \\
\text { units }\end{array}$ & $\begin{array}{c}\mathbf{N}^{\mathbf{0}} \text { of Health } \\
\text { personnel }\end{array}$ & $\begin{array}{c}\text { Portable } \\
\text { water } \\
\text { stands }\end{array}$ & $\begin{array}{l}\text { Common causes of } \\
\text { death } \\
\text { (Hospital cases) }\end{array}$ & $\begin{array}{c}\text { Average } \\
\text { annual } \\
\text { deaths }\end{array}$ \\
\hline Mbai & 02 & 04 & 26 & $\begin{array}{l}\text { Typhoid, exposure to } \\
\text { cold, accidents and } \\
\text { landslides }\end{array}$ & 22 \\
\hline $\begin{array}{l}\text { Emfve- } \\
\text { miih }\end{array}$ & 06 & 22 & 56 & $\begin{array}{l}\text { Typhoid, exposure to } \\
\text { cold and accidents }\end{array}$ & 25 \\
\hline Mbam & 04 & 07 & 34 & $\begin{array}{l}\text { Landslides, poor } \\
\text { traditional practices } \\
\text { and wars }\end{array}$ & 14 \\
\hline Shinga & 03 & 05 & 32 & $\begin{array}{l}\text { Road accidents, } \\
\text { landslides and poor } \\
\text { traditional practices }\end{array}$ & 20 \\
\hline Others & 02 & 02 & 06 & Exposure to diseases & 11 \\
\hline Total & 17 & 40 & 154 & & 92 \\
\hline
\end{tabular}

Source: Elak District hospital, 2012; Fieldwork, 2017-2018.

Based on the annual average mortality rate, 3312 people have died in Oku from poor access to healthcare delivery between 1982-2018. Emfve-miih is hardest hit due to high population density that weighs on the health institutions. The Director of the Elak District Hospital and other health personnel in the health posts remarked that the population size is fast outweighing the doctor to patient ratio (Table 3) and that most patients in Oku adhere so much to their traditional medication especially the men and only solicit modern medication when their health is in critical condition. In most cases, they end up dying in the hospital or not going to the main hospital (Banso Baptist Hospital) due to poverty. The human capital for development is reduced through the fall in labour force. This is in line with Ulla and Tapio (2011) who pointed out that main cause of underdevelopment in Sub-Saharan Africa is limited access to medication and poor health conditions of the population (table 4). 
Table 4: Average Doctor to patient ratio in the different villages

\begin{tabular}{|l|c|c|c|}
\hline Zone & $\begin{array}{c}\text { Number of } \\
\text { villages }\end{array}$ & $\begin{array}{c}\text { Total population in } \\
\mathbf{2 0 1 2}\end{array}$ & $\begin{array}{c}\text { Average Doctor to Patient } \\
\text { ratio }\end{array}$ \\
\hline Mbai & 05 & 10523 & $1: 2104.6$ \\
\hline Emfuehmih & 17 & 66690 & $1: 3922.9$ \\
\hline Mbam & 08 & 17553 & $1: 2194.1$ \\
\hline Shinga & 06 & 30834 & $1: 5139$ \\
\hline Others & 07 & 19200 & $1: 2742.9$ \\
\hline
\end{tabular}

Source: Calculated from Elak Council Development Plan, 2012

The ratio is fairly higher in the villages found in Mbai Zone because of the lower population figures compared to the others and also due to the fact that the number of villages are few. On the contrary the lower ratio in the Shinga is due to its high population in the area and difficult accessibility for the health personnel. Field evidence indicates that most health personnel posted to the area do not take up the appointment. High rates of mortality of $7.6 \%$ annually are also a function of human exposure to land disputes and intertribal wars especially villages in border localities since 1982 as revealed in Table 5.

Table 5: Socio-cultural and political causes of mortality in Oku and casualties between 1982 and

\begin{tabular}{|l|l|c|c|l|l|}
\hline Period & Conflicts & $\begin{array}{c}\mathbf{N}^{\mathbf{0}} \text { of } \\
\text { deaths } \\
\text { recorded }\end{array}$ & $\begin{array}{c}\mathbf{N}^{\mathbf{0}} \text { of } \\
\text { men } \\
\text { missing }\end{array}$ & $\begin{array}{c}\text { Major causes } \\
\text { Of mortality }\end{array}$ & \multicolumn{1}{|c|}{$\begin{array}{c}\text { Villages most } \\
\text { affected }\end{array}$} \\
\hline $\begin{array}{l}1982, \\
2007-2008\end{array}$ & $\begin{array}{l}\text { Oku and } \\
\text { Mbessa }\end{array}$ & 70 & 12 & $\begin{array}{l}\text { Struggle over a } \\
\text { hollow frontier } \\
\text { called Koh Embel }\end{array}$ & $\begin{array}{l}\text { Ichim, Ibalichem, } \\
\text { Ndum, Ngham }\end{array}$ \\
\hline 1997 & Oku and & 17 & 05 & $\begin{array}{l}\text { Struggle over a } \\
\text { hollow frontier } \\
\text { called 'Bahluh' }\end{array}$ & $\begin{array}{l}\text { Mbam, Fekeng and } \\
\text { Nkwi, Chak and } \\
\text { Manchok }\end{array}$ \\
\hline 1997 & $\begin{array}{l}\text { Oku and } \\
\text { the State }\end{array}$ & 12 & 06 & $\begin{array}{l}\text { Southern } \\
\text { Cameroon } \\
\text { rebellion }\end{array}$ & $\begin{array}{l}\text { Elak, Manchok } \\
\text { Keyong and } \\
\text { Jikejem }\end{array}$ \\
\hline $2007-2008$ & $\begin{array}{l}\text { Oku and } \\
\text { Nso }\end{array}$ & 05 & $/$ & $\begin{array}{l}\text { Struggle over a } \\
\text { hollow frontier } \\
\text { called Tankiy and } \\
\text { buuhkuh }\end{array}$ & $\begin{array}{l}\text { Tankiy, Simonkoh } \\
\text { and Mbockenghas }\end{array}$ \\
\hline Total & the state & 47 & 12 & $\begin{array}{l}\text { Southern } \\
\text { Cameroon } \\
\text { rebellion }\end{array}$ & All the villages \\
\hline
\end{tabular}

Source: The Post Newspaper, 2007; Elak Parish Achives, 2009; Oku Fon's Palace, 2018; Nchinda, 2015; Banso Baptist Hospital, 2017 and Fieldwork, 2018

These casualties are seen more in the most destructive conflicts with a long standing history being the Oku-Mbessa conflict. This is due to its frequency and the exposure of the population to barbarism during the events. Neighbourhoods closer to theses frontiers suffered the loss of more 
development assets than areas from far off localities. The total number missing are considered by their family members as haven died in the course of the conflicts.

\subsubsection{Effects of Inter-Tribal Conflicts on Development}

From table 3, a total of 104 Oku people mostly from the male youthful population have lost their lives in conflicts from 1982-2008. A total of 23 males were reportedly missing during these conflicts, considered to have died (household surveys, 2018). This brings the death toll resulting from conflicts to 127 people. Tens and hundreds of houses and huts destroyed and burnt down (62 in 1982, 38 in 1997, 22 in 1995 and 210 from 2007-2008) (Bailack and Fogwe); orchestrated internal displacements and outward migrations of an estimated 1500 people (loss of labour force) of the youthful age group and food insecurity in the subsequent post conflicts years. This is resolutely consistent with the views of Jesse et al. (2013) which concluded that the lower level of development in Puma is conflicts and migration-related deaths. All these reduced the human resource-base (financial contributions and services offered through family and community labour) and other assets (farm output and infrastructure) for development thereby slowing down community development in these villages. According to a former president of the Oku Cultural and Development Association, significant financial community contributions to the development Oku were only significant from 2012 as the community was more stable from inter-tribal unrest. This is the particular case of Ibalichim, Ndum, Ngham, Chak, Ketongwang and Tankiy. This is supported by Nchinda (2015) who though did not consider the loss of farm output in conflicts but remarked that disputes with violent conflict episodes in 1997 crippled the social, economic and political life of Oku creating internally displaced persons, much resources spend on the masses rehabilitated and the stagnation of economic activities.

Economically most of the people are poor and about $98 \%$ depend on agriculture for survival. Several crops and farmlands destroyed (worth over \$700 in 1982 alone)). Standards of living are poor and most of the people are less privileged. Affordability to healthcare is far-fetched due to low incomes caused by these conflicts increasing the death toll. As opposed to Javier (2007) who considered improved development resulting from reduction in mortality as a result of increased healthcare affordability in the $20^{\text {th }}$ and $21^{\text {st }}$ Century, field investigations from the Elak District Hospital indicate that many people are unable to pay for their treatment especially during periods of influx landslide victims, the wounded in the conflicts and the displaced. All the effects of human-induced mortality incidences corroborates the fact that death rate and property damage are commonly used to measure the socio-economic impact in the area which are indices of development (WHO, 2010).

This study was based on the premise that human-induced mortality incidence limits to an extent the socio-economic development of the area. A chi square test is used to test this proposition as illustrated in Table 6.

Table 6: Chi-Square Tests for human mortality and socio-economic development

\begin{tabular}{|l|c|c|c|}
\hline & Value & df & Asymp. Sig. (2-sided) \\
\hline Pearson Chi-Square & $164.623^{\text {a }}$ & 6 & .000 \\
\hline Likelihood Ratio & 146.862 & 6 & .000 \\
\hline Linear-by-Linear Association & 47.590 & 1 & .000 \\
\hline
\end{tabular}


\begin{tabular}{|l|l}
$\mathrm{N}$ of Valid Cases & 241 \\
\hline
\end{tabular}

a. 3 cells $(25.0 \%)$ have expected count less than 5 . The minimum expected count is 2.19 .

Source: Fieldwork, 2018

Table 6 shows a significant inverse association between mortality and socioeconomic development in Oku $\left(\mathrm{X}^{2}=164.623, \mathrm{df}=6, \mathrm{p}=0.00<0.05\right)$ as confirmed by the chi-square $\left(\mathrm{X}^{2}\right.$ Cal $\left.=164.623\right)$ being greater that the critical chi-square $\left(\mathrm{X}^{2}\right.$ Crit $\left.=12.59\right)$. This analysis alludes to the fact that rising mortality numbers especially in periods of landslides, and conflicts and in an environment, which has poor healthcare facilities, spatiotemporally reduce the assets for development through loss in labour force and income for community development. This therefore confirms the fact that humaninduced mortality incidence limits to an extent or is a deterrent to the socio-economic development of Oku Sub-Division.

\subsubsection{Human Response and Mitigations to Human-Induced Hazards}

The reaction to human-induced mortality in Oku is still very timid though improving compared to the previous situations (between 1982 and 2010). Many people are now being educated on how to evade human induced mortality. To solve the problems of farming on steep slopes, most villagers now prefer migrating to hollow frontiers like Bahluh (closer to Mbam Zone); Buhkuh, Mgissi and Baseh (closer to Mbai and Emfuehmih Zone) and Babungo (closer to Shinga Zone) area for food security rather farming on the steep slopes. These frontiers are nearer to border villages and have plains and fertile soils that attract agriculture. These space dynamics poses another problem; that of pressure on limited resources.

Slope stabilization measures are also adopted seen with the building of embankments and houses constructed on steep slopes though adopted only by the wealthier class as it is too expensive for majority of the population which are poor. Sensitisation has sent many parents eager and ready to always vaccinate their children and many people are tilting their attention towards modern medication. The challenge here is the expensive nature of modern healthcare facilities compared to traditional medication for the population and poverty to adopt better engineering norms to check against soil creep and landslides.

\section{Conclusion}

There is a high nexus between mortality and nature of the environment. Studies have revealed that the high mortality levels in Oku has adversely been the result of the undulating topography whereby the local population has been obliged to develop housing and undertake agricultural activities at the mercy of extreme weather, landslides and other related hazards. Though death rates are still high $(7.6 \%)$, birth rates are higher $(139 \%)$ (Elak Council Development Plan, 2017) denoting a slow positive population change and development efforts decelerated as human exposure to physical and human variables constrain chances for investments in Oku and other rural areas. Further findings from the Chii Square Test at the degree of freedom of 6 at 0.05 level of significance; indicate that human-induced mortality is a deterrent to socio-economic development in Oku Sub-Division. Further findings indicate that human-induced mortality impacts are more of a deterrent to socio-economic development in Oku Sub-Division as the implications are very severe. This is in consistent analysis of the World Bank (2007); Centre for Development and 
Environment (2017) as opined that mortality and development are inversely related. There are many local and national efforts that are being engaged to redress these mortality incidences so as to put this area on a sustainable development path.

\section{References}

[1] Ayres J. G. and Hurley J. F. The Mortality Effects of Long-Term Exposure to Particulate Air Pollution in the United Kingdom. Produced by the Health Protection Agency for the Committee on the Medical Effects of Air Pollutants. COMEAP Secretariat, www.comeap.org.uk, 2010.

[2] Bailack K. M. and Fogwe Z. N. Land Resource Conflict Mitigation Diplomacy for Harmonious Inter communities' Coexistence: The Oku-Mbessa Legacy in the North West Region of Cameroon. International Journal of Current Research Vol. 11, Issue, 07, July, 2019, 5628-5635.

[3] Centre for Development and Environment. Safer Lives and Livelihoods in Mountains. Making the Sendai Framework for Disaster Risk Reduction Work for Sustainable Mountain Development. Sustainable Mountain Development Series. University of Bern, Switzerland, 2017.

[4] Cutler D., Angus D. and Adriana L. The Determinants of Mortality, Journal of Economic Perspectives, Vol. 20, No. 3, 2006, 97-120.

[5] Elak Council. Elak Council Development Plan, Elaborated with the support of the National Community Driven Development Program (PNDP), 2017.

[6] Fogwe Z. N. and Kwei J. Cameroonian Protected Kilum Ijim Forest for the Development of Oku Forest Fringe Communities, E3 Journal of Resource and Environmental Management, Vol. 6 (5), 2015, 293-303.

[7] Fogwe Z. N. Mitigating and Managing Regional Geo-environmental Hazards within a Decentralisation Transition in Cameroon, Journal of Human Ecology, Delhi, India. 2010.

[8] Javier A. B. Economic development and the escape from high mortality. World DevelopmentVol.35, No.4, 2007,543-568.

[9] Jesse N., Scott M., Toni R., Daniel P., Michael M. H., Kerry M., Rich S. Human Caused Mortality Influences Spatial Population Dynamics: Pumas in Landscapes with Varying Mortality Risks, Journal of Biological Conservation, 2013.

[10] Lucyna S. Overall Human Mortality and Morbidity due to Exposure to Air Pollution, International Journal of Occupational Medicine and Environmental Health, 29 (3): 2016, 417 - 426.

[11] Nchinda D.K.. SCNC Rebellion in Oku, Bui Division, North West Region of Cameroon. Scholars Journal of Arts, Humanities and Social Sciences Soc. Sci., 2015, 869-880.

[12] Tangwa N. M. Effects of increasing mortality on the population structure of Oku, Bsc Dissertation, University of Buea. 2009. Unpublished.

[13] The Post Newspaper February 2007 edition. 13p

[14] Ulla Lehmijoki and Tapio Paloka. The Long-Run Effects of Mortality Decline in Developing Countries, Discussion Paper No. 5422, 2011.

[15] UNICEF. Humanitarian Action for Children in West and Central Africa, Planned Humanitarian Action for 2011, 2011.

[16] UNO. Levels \& Trends in Child Mortality, 2015Eestimates Developed by the UN Inter-Agency Group for Child Mortality Estimation, United Nations, Department of Economic and Social Affairs, Population Division 2015.

[17] UNO. World Mortality Report by the UN Inter-agency Group for Child Mortality Estimation, United Nations, Department of Economic and Social Affairs, Population Division, World Mortality 2017 Data Booklet (ST/ESA/SER.A/412), 2017.

[18] WHO. Global Status Report on Non-Communicable Diseases, Chronic Disease - Prevention and Control, Chronic Disease - Epidemiology, Chronic Illness, Delivery of Health care 2010.

[19] Windsor J.S, Firth P.G, Grocott M.P, Rodway G.W, Montgomery H.E. Mountain mortality: A review of deaths that occur during recreational activities in the mountains 2014. 
[20] World Bank. Aggregate Income Shocks and Infant Mortality in the Developing World, Development Research Group, Policy Research Working Paper, 4346, 2007.

[21] Yungui H. and Samuel H. Medical Effects of Air Pollutants, Modelling Mortality Risk from Exposure to a Potential Future Extreme Event and its Impact on Life Insurance, Georgia State University Atlanta, Georgia 2005.

* Corresponding author.

E-mail address: mbuhbailack@gmail.com/ezume@hotmail.com 